\title{
Evaluating energy intake measurement in free-living subjects: when to record and for how long?
}

\author{
Claire L Fyfe ${ }^{1}$, Joanne Stewart ${ }^{1}$, Sandra D Murison ${ }^{1}$, Diane M Jackson ${ }^{1}$, Kellie Rance ${ }^{1}$, \\ John R Speakman ${ }^{2}$, Graham W Horgan ${ }^{3}$ and Alexandra M Johnstone ${ }^{1, *}$ \\ 'Division of Obesity and Metabolic Health, Rowett Institute of Nutrition and Health, University of Aberdeen, \\ Aberdeen AB21 9SB, UK: ${ }^{2}$ School of Biological Sciences, University of Aberdeen, Aberdeen, UK: \\ ${ }^{3}$ Biomathematics and Statistics Scotland, Aberdeen, UK
}

Submitted 10 February 2009: Accepted 29 July 2009: First published online 22 September 2009

\begin{abstract}
Objective: To nutritionally analyse mean energy intake (EI) from different $3 \mathrm{~d}$ intervals within a $7 \mathrm{~d}$ recording period and to evaluate the seasonal effect on energy and nutrient intake.

Design: Cross-sectional study of dietary intake collected with $7 \mathrm{~d}$ food diaries.

Setting: Aberdeen, north-east Scotland, UK, between 2002 and 2004.

Subjects: Participants from two long-term trials were pooled. These trials, investigating genetic and environmental influences on body weight, were the Genotyping And Phenotyping (GAP) study and a cohort observational study, Rowett Assessment of Childhood Appetite and metaboLism (RASCAL). There were 260 Caucasian adults, BMI range $16 \cdot 7-49 \cdot 3 \mathrm{~kg} / \mathrm{m}^{2}$, age range $21-64$ years.

Results: Mean EI for Wednesday, Friday and Saturday had the closest approximation to the $7 \mathrm{~d}$ mean $(0 \cdot 1 \%$ overestimate $)$. A gender $\times$ season interaction $(P=0 \cdot 019)$ with a different intake pattern for females and males was observed. For females, lower mean (SE) EI was recorded in summer $(8117(610) \mathrm{kJ})$ and autumn (7941 (699) kJ) compared with spring (8929 (979) kJ) and winter (8132 $(1041) \mathrm{kJ}$ ). For males, higher mean (sE) EI was recorded in summer (10 420 (736) kJ) and autumn (10 490 (1041) kJ) compared with spring (9319 (1441) kJ) and winter (9103 (1505) kJ).

Conclusions: The study results indicate that $3 \mathrm{~d}$ weighed intakes recorded from Wednesday, Friday and Saturday are most representative of $7 \mathrm{~d}$ habitual intake in free-living subjects. They also indicate that seasonality has a limited effect on EI and no effect on macronutrient intake.
\end{abstract}

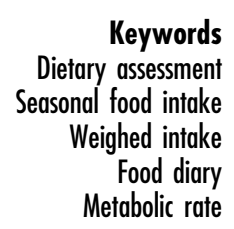

Weighed diet records are considered the 'gold standard' when examining free-living energy and nutrient intake, with seven days of recording regarded as the best compromise between accuracy, investigator workload and subject compliance ${ }^{(1)}$. In practice however, $3 \mathrm{~d}$ weighed dietary records are often the assessment tool chosen by investigators for intervention studies, as they are deemed to be less intrusive for subjects ${ }^{(2)}$ and can therefore improve subject recruitment. With the shorter recording period comes the concern whether the three recording days are representative of habitual intake ${ }^{(3)}$. Therefore, much research has focused on identifying feasible intakes and attempting to correct intake data. Specifically, the effects of 'misreporting' or 'under-reporting' of food intake $^{(4)}$ has been a main focus of attention, following better energy expenditure (and thus energy balance) methodology ${ }^{(5)}$. Within the literature, there has been less emphasis on the practical issues such as when to ask subjects to record, i.e. which day(s) or the effect of season, which may have an effect on achieving an assessment of habitual intake. Hartman et al. ${ }^{(6)}$ reported that non-consecutive days were preferable due to a correlation between eating behaviour on consecutive days and Bingham ${ }^{(7)}$ recommended a $3 \mathrm{~d}$ diary to include one weekend day and two weekdays, since weekend days are known to indicate higher reported energy intakes ${ }^{(8,9)}$. Food intake patterns have changed since these recommendations were made over 20 years ago ${ }^{(10)}$, with the potential that intake towards the end of the working week may reflect similar patterns to weekend intake. It is also anecdotally thought that season can affect food patterns, e.g. increased salad intake in summer and soup intake in winter, but it is not clear whether this actually influences habitual nutrient intake.

Thus, the aims of the present study were: (i) to compare different $3 \mathrm{~d}$ periods with the $7 \mathrm{~d}$ mean to identify if a shorter recording period is representative of habitual intake; and (ii) to compare energy and nutrient results 
from different seasons to assess if seasonality has an effect on energy and nutrient intake. The weekday and weekend energy and nutrient intakes were also analysed to assess whether our results agree with previous findings ${ }^{(8,9)}$. All of these issues could have practical implications for large nutritional assessment studies where baseline data are collected over a prolonged time.

\section{Materials and methods}

\section{Subject characteristics}

Data from two nutritional studies based at the Human Nutrition Unit, Rowett Institute of Nutrition and Health, Aberdeen, UK, were pooled for the present analysis, totalling 260 adult subjects.

Subjects were recruited for Study 1 by newspaper advertisement to participate in a study investigating genetic and environmental influences on body weight, why do some people gain weight more easily than others? The aim of the Genotyping And Phenotyping (GAP) study was to explore the hypothesis that the susceptibility of people to be obese results from an interaction between environment and genotype. Measurements of metabolism, food intake, physical activity and health status (e.g. blood pressure, cholesterol) were carried out over a period of $8 \mathrm{~d}$ to phenotype and genotype obese individuals to determine if there was an interaction present. More details on this study population are given elsewhere ${ }^{(11,12)}$.

Study 2 was a cohort observational study recruiting whole families; more details of this study population are given elsewhere $^{(13,14)}$. The aim of the Rowett ASsessment of Childhood Appetite and metaboLism (RASCAL) study was to investigate how much influence genetic and environmental factors have on a child's susceptibility or resistance to becoming overweight. The same measurements of metabolism, food intake, physical activity and health status recorded in the GAP study were carried out on the RASCAL families. The data from the children participating in the RASCAL study are not analysed in the current paper.

For both studies, subjects were only included if they were not eating any special diet; had stable weight (weight change of no more than $2 \mathrm{~kg}$ in the previous 3 months); and were otherwise healthy, based on a medical examination and by contacting their general practitioner for recent medical and medication status. They took no regular prescribed medication, vitamin or mineral supplements, with the exception of the contraceptive pill or hormone replacement therapy for women. The North of Scotland Research Ethics Service approved both studies. Written informed consent was obtained.

\section{Measurement of baseline antbropometry and BMR}

Subjects attended for measurements of body composition and metabolic rate $\left(\mathrm{BMR}_{\text {meas }}\right)$ under standardised fasted conditions. Subjects were instructed not to consume caffeinated products or to smoke prior to attending the unit, and arrived between 07.00 and 08.30 hours. They were allowed to relax for about $30 \mathrm{~min}$ prior to measurements being conducted. Height was measured to the nearest $0 \cdot 1 \mathrm{~cm}$ using a stadiometer (Holtain Ltd, Crymych, UK). Subjects were weighed after voiding, wearing light clothing, to the nearest $100 \mathrm{~g}$ on a digital scale (DIGI DS410; CMS Weighing Equipment Ltd, London, UK). BMR was measured by indirect calorimetry over 30-40 min using a ventilated hood system (Deltatrac II, MBM-200; Datex-Ohmeda Instrumentarium Corporation, Helsinki, Finland). During the measurement, subjects lay on a bed in a thermoneutral room and were instructed to lie still but not to fall asleep. BMR was calculated from minuteby-minute data, using the equations of Livesey and Elia $^{(15)}$. This method analyses the mean of $15 \mathrm{~min}$ of stable measurements, with the first and last 5 min excluded. Details of calibration burns and repeatability testing have been described previously ${ }^{(11)}$.

Early on in the analysis process we removed data from apparent 'under-reporters'. The EI:BMR meas ratio was calculated for each subject and compared with the two cut-off points defined by Goldberg et al. ${ }^{(16)}$ and Black et $a l .{ }^{(1)}$. Where $\mathrm{BMR}_{\text {meas }}$ data were missing for twenty-four subjects, estimated BMR ( $\left.\mathrm{BMR}_{\text {est }}\right)$, as defined by Schofield $^{(17)}$, was used instead. There were eighty-nine subjects (35\%) below cut-off 1 and thirty-four subjects (13\%) below cut-off 2 , with the remaining 132 subjects ( $52 \%$ ) above cut-off 1 . The same significant trends were observed between the results from the original data set and that of the data set minus the under-reporters. There was no discernible bias observed for gender. The mean $\mathrm{EI}: \mathrm{BMR}_{\text {meas }}$ for all subjects was 1.39 (SE $0 \cdot 02$; range $0 \cdot 60-2 \cdot 40$ ). We therefore present the results from the full data set in the current paper.

\section{Food intake recording}

For measurement of food and macronutrient intake, subjects in Study 1 (GAP) were asked to record all foods and drinks consumed for a consecutive $7 \mathrm{~d}$ period, using weighed dietary record methodology. They were provided with digital electronic scales (Soehnle model 820; Soehnle-Waagen GmbH \& Co. KG, Murrhardt, Germany), which have a tare facility and weigh up to $1 \mathrm{~kg}$ with a resolution of $1 \mathrm{~g}$. The scales were calibrated before each measurement period at four points over the scale's range using reference weights (Thomson Scientific, Cults, Aberdeen, UK). Subjects were also provided with a food diary notebook for recording a description of the food or drink, time of consumption, weight of food, cooking method and leftovers. They were encouraged to record all recipe formulations and to keep all packaging for ready-to-eat food products, as described by Bingham ${ }^{(7)}$. When the use of the scales was difficult, e.g. when eating out, the subjects were instructed to record as much information as possible about the quantity of the food 
they ate by using household measures (tablespoon, cup, slice, etc.). It has been previously reported that to be effective, the dietary record must provide adequate detail not only of the types of foods consumed but also details of the way in which they were prepared for consumption $^{(18)}$. The subjects were therefore asked to indicate where applicable how their food was cooked (boiled, fried, baked, etc.) to assist analysis. A similar technique was used in the RASCAL study; subjects recorded their food intake for $7 \mathrm{~d}$ in a food diary but, due to measurement constraints, the foods were not weighed. Instead food portion sizes were estimated using images from the food portion atlas ${ }^{(19)}$. Both of these methods of food intake recording have different strengths ${ }^{(20)}$. Weighed intakes rely less on memory as portion size is recorded directly at the time of measurement. Un-weighed intakes place lower burden on subjects, who are therefore less likely to alter eating behaviour. From issues raised by Friedenreich $^{(21)}$ regarding pooled data, statistical analysis was carried out to compare the results from both studies. This was to ensure that there was no significant difference in results due to recording methodology (weighed $v$. unweighed intakes). The difference in results was not significant; therefore the data were pooled.

\section{Analysis of food intake data}

All diets from both studies were analysed by trained staff using the WinDiets Nutritional Analysis Software Suite version 1.0 (The Robert Gordon University, Aberdeen, UK), a computerized version of McCance and Widdowson's The Composition of Foods ${ }^{(22)}$. To input foods recorded with household measures, or with missing weights or portion sizes, standard portions sizes were used $^{(23)}$. Thus, total food energy and nutrient intake for every meal could be quantified. To reduce investigator bias and inputting errors, all diets were cross-checked by at least one other trained member of staff. The database of nutritional information was updated for unusual food products (from food packaging provided by subjects).

In order to examine seasonal effects of when intake was recorded, we designated the following classifications: spring was defined as March to May, summer was June to August, autumn was September to November and winter was December to February.

Weekdays were considered to be Monday to Friday inclusively, weekend as Saturday and Sunday. The $3 \mathrm{~d}$ diary periods examined were Tuesday-Thursday-Saturday, Wednesday-Friday-Sunday and Thursday-Saturday-Monday, following the suggestions of Hartman et al. ${ }^{(6)}$ to use non-consecutive days of recording and of Bingham ${ }^{(7)}$ to include one weekend day and two weekdays.

\section{Statistical analysis}

Bland and Altman plots ${ }^{(24)}$ were examined to compare the results for $3 \mathrm{~d}$ and $7 \mathrm{~d}$ EI $(\mathrm{kJ} / \mathrm{d})$. The differences were calculated as the $3 \mathrm{~d}$ average minus the $7 \mathrm{~d}$ average. Intakes were analysed by hierarchical (splitplot) ANOVA with terms for study, gender, season and their interaction in the subject stratum, and weekday and its interaction with study and gender in the within-subject stratum. Subject age and BMI were included as covariates. All data were analysed using the GenStat for Windows statistical software package 9th edition (GenStat Committee; VSN International, Hemel Hempstead, UK). Results are expressed as mean and standard error of the mean, with $P$ values below 0.05 considered indicative of a statistically significant effect.

For purposes of presentation of trends, the data were split first by study (GAP, $n$ 150; RASCAL, $n$ 110), then by gender (females, $n$ 169; males, $n$ 91), BMI (normal weight, BMI $\leq 24.9 \mathrm{~kg} / \mathrm{m}^{2}, n 123$; overweight and obese, $\left.\mathrm{BMI} \geq 25 \cdot 0 \mathrm{~kg} / \mathrm{m}^{2}, n 127\right)$ and age (21-44 years, $n 177$; 45-64 years, $n$ 83).

\section{Results}

\section{Subject characteristics}

There were 260 subjects in total (169 females, ninety-one males), with a mean age of $40 \cdot 1$ (se $0 \cdot 6$ ) years (range 21-64 years) and a mean BMI of $26 \cdot 0(\mathrm{SE} 0 \cdot 4) \mathrm{kg} / \mathrm{m}^{2}$ (range $16 \cdot 7-49 \cdot 3 \mathrm{~kg} / \mathrm{m}^{2}$ ). There were 150 subjects in Study 1 (GAP; 107 females, forty-three males). The GAP subjects were, on average, 43.7 (SE 0.9) years of age (range 21-64 years) with a mean BMI of $26.5($ SE 0.5$) \mathrm{kg} / \mathrm{m}^{2}$ (range $16 \cdot 7-49 \cdot 3 \mathrm{~kg} / \mathrm{m}^{2}$ ). There were 110 adults in Study 2 (RASCAL; sixty-two females, forty-eight males), with a mean age of $35 \cdot 5$ (SE 0.5 ) years (range $23-50$ years) and a mean BMI of $25 \cdot 8 \quad(\mathrm{se} \quad 0.5) \mathrm{kg} / \mathrm{m}^{2}$ (range $\left.20 \cdot 3-46 \cdot 3 \mathrm{~kg} / \mathrm{m}^{2}\right)$.

\section{Energy intake: $7 \mathrm{~d}$ results}

The mean $7 \mathrm{~d}$ EI results (range 3878-16688 kJ) are shown in Table 1. The difference in mean EI between the GAP and RASCAL studies (GAP mean was $-202 \mathrm{~kJ}, 2 \cdot 3 \%$ lower) was not significant and, on this basis, we pooled the data. Males reported a $1909 \mathrm{~kJ}(19 \%, P<0 \cdot 001)$ higher EI than females and younger subjects ate slightly more $(590 \mathrm{~kJ}, 6 \cdot 5 \%, P<0 \cdot 001)$ than the older subjects; however, obese and lean subjects reportedly ate a similar amount $(97 \mathrm{~kJ}, 0.97 \%, P=0.351)$. The UK Department of Health Estimated Average Requirements ${ }^{(25)}$ for EI is $10676 \mathrm{~kJ}$ for males and $8122 \mathrm{~kJ}$ for females. Our results are $5 \%$ lower $(559 \mathrm{~kJ})$ and $1 \%$ higher $(76 \mathrm{~kJ})$, for males and females, respectively. The EI:BMR ratio was calculated by dividing average $7 \mathrm{~d}$ EI by measured or estimated BMR. There was a significant difference in EI:BMR between BMI groups (13\% greater in overweight compared with normal weight, $P<0 \cdot 001$ ) but not between age groups ( $4 \%$ difference, $P=0 \cdot 244$ ). 
Table 17 d energy intake among Caucasian adults ( $n$ 260), Aberdeen, north-east Scotland, UK, 2002-2004

\begin{tabular}{|c|c|c|c|c|c|c|}
\hline & & \multirow[b]{2}{*}{ Gender $(n)$} & \multicolumn{2}{|c|}{ Energy (kJ) } & \multicolumn{2}{|c|}{ El:BMR } \\
\hline & & & Mean & SE & Mean & SE \\
\hline Study & $\begin{array}{l}\text { GAP } \\
\text { RASCAL }\end{array}$ & $\begin{array}{l}\text { Male (43) } \\
\text { Female (107) } \\
\text { Both }(150) \\
\text { Male (48) } \\
\text { Female (62) } \\
\text { Both (110) }\end{array}$ & $\begin{array}{c}9917^{\mathrm{a}} \\
8322^{\mathrm{b}} \\
8787 \\
10266^{\mathrm{a}} \\
7978^{\mathrm{b}} \\
8993\end{array}$ & $\begin{array}{l}360 \\
178 \\
174 \\
295 \\
217 \\
208\end{array}$ & $\begin{array}{l}1 \cdot 35 \\
1 \cdot 46^{\mathrm{a}} \\
1 \cdot 43 \\
1 \cdot 40 \\
1 \cdot 31^{\mathrm{b}} \\
1 \cdot 35\end{array}$ & $\begin{array}{l}0.05 \\
0.03 \\
0.03 \\
0.04 \\
0.04 \\
0.03\end{array}$ \\
\hline Gender & & $\begin{array}{l}\text { Male (91) } \\
\text { Female (169) }\end{array}$ & $\begin{array}{r}10117^{\mathrm{a}} \\
8198^{\mathrm{b}}\end{array}$ & $\begin{array}{l}230 \\
138\end{array}$ & $\begin{array}{l}1 \cdot 38 \\
1 \cdot 40\end{array}$ & $\begin{array}{l}0.03 \\
0.06\end{array}$ \\
\hline BMI & $\begin{array}{l}\text { Normal: } \mathrm{BMI} \leq 24 \cdot 9 \mathrm{~kg} / \mathrm{m}^{2} \\
\text { Overweight: } \mathrm{BMI} \geq 25 \cdot 0 \mathrm{~kg} / \mathrm{m}^{2}\end{array}$ & $\begin{array}{l}\text { Male (33) } \\
\text { Female (90) } \\
\text { Both (123) } \\
\text { Male (54) } \\
\text { Female (73) } \\
\text { Both (127) }\end{array}$ & $\begin{array}{c}10696^{\mathrm{a}} \\
8267^{\mathrm{b}} \\
8916 \\
9668^{\mathrm{a}, \mathrm{b}} \\
8178^{\mathrm{b}} \\
8829\end{array}$ & $\begin{array}{l}438 \\
178 \\
200 \\
261 \\
224 \\
182\end{array}$ & $\begin{array}{l}1 \cdot 51^{\mathrm{a}} \\
1 \cdot 49^{\mathrm{a}} \\
1 \cdot 49^{\mathrm{a}} \\
1 \cdot 28^{\mathrm{b}} \\
1 \cdot 31^{\mathrm{b}} \\
1 \cdot 30^{\mathrm{b}}\end{array}$ & $\begin{array}{l}0.06 \\
0.03 \\
0.03 \\
0.04 \\
0.04 \\
0.03\end{array}$ \\
\hline Age & $\begin{array}{l}\text { Younger: } 21-44 \text { years } \\
\text { Older: } 45-64 \text { years }\end{array}$ & $\begin{array}{l}\text { Male (60) } \\
\text { Female (117) } \\
\text { Both (177) } \\
\text { Male (31) } \\
\text { Female (52) } \\
\text { Both (83) }\end{array}$ & $\begin{array}{c}10450^{\mathrm{a}} \\
8321^{\mathrm{b}} \\
9068^{\mathrm{a}} \\
9405^{\mathrm{a}, \mathrm{b}} \\
7907^{\mathrm{b}} \\
8472^{\mathrm{b}}\end{array}$ & $\begin{array}{l}284 \\
171 \\
167 \\
370 \\
228 \\
214\end{array}$ & $\begin{array}{l}1 \cdot 41 \\
1 \cdot 41 \\
1 \cdot 41 \\
1 \cdot 30 \\
1 \cdot 39 \\
1 \cdot 36\end{array}$ & $\begin{array}{l}0.04 \\
0.03 \\
0.02 \\
0.06 \\
0.05 \\
0.04\end{array}$ \\
\hline
\end{tabular}

GAP, Genotyping And Phenotyping study; RASCAL, Rowett Assessment of Childhood Appetite and metaboLism.

${ }^{\mathrm{a}, \mathrm{b}}$ Mean values within a column with unlike superscript letters were significantly different $(P<0 \cdot 05)$.

\section{Weekday (Monday-Friday) v. weekend (Saturday-Sunday) energy intakes}

Figure 1 shows mean (SE) EI by day of the week and indicates that weekend intakes were significantly greater than weekdays $(P<0 \cdot 001)$, with average intakes of $9830(219) \mathrm{kJ}$ and 9126 (183) kJ on Saturday and Sunday, respectively, in comparison to an average of 8634 (82) kJ for weekdays. This represents a $10 \%$ increase on these days.

\section{Weekday v. weekend macronutrient intakes}

Mean macronutrient intakes were examined to explore the variance observed in EI between weekdays and weekend days. The results (mean (SE)) were $12 \%$ higher (2896 (40) kJ $v .3248(64) \mathrm{kJ}, P<0 \cdot 001)$ for fat intake, $6 \%$ higher (1329 (15) kJ $v .1416(26) \mathrm{kJ}, P=0 \cdot 003)$ for protein intake and $78 \%$ higher $(356(20) \mathrm{kJ} \quad v .627$ (46) kJ, $P<0 \cdot 001)$ for alcohol intake on weekend days $v$. weekdays, respectively. The difference in carbohydrate intake, a $3 \%$ increase, was not significant $(4023(41) \mathrm{kJ} v .4148$ (67) kJ, $P=0 \cdot 110$ ) between weekdays and weekend days, respectively.

\section{$7 d$ v. $3 d$ energy intakes}

Mean (sE) EI for the $3 \mathrm{~d}$ periods Tuesday-Thursday-Saturday (9018 (115) kJ), Wednesday-Friday-Saturday (8885 (106) kJ) and Thursday-Saturday-Monday (9015 (116) kJ) were not significantly different $(2 \cdot 6 \%$ higher, $0 \cdot 1 \%$ and $1.6 \%$, lower respectively) from the $7 \mathrm{~d}$ mean (8874 $(72) \mathrm{kJ})$. Bland-Altman plots of the $3 \mathrm{~d} v .7 \mathrm{~d}$ energy intakes with $95 \%$ confidence limits $( \pm 2 \mathrm{sD}$ ) can be seen in Fig. 2. In all $3 \mathrm{~d}$ periods $v .7 \mathrm{~d}$ there is an upward trend, the difference becomes more positive at greater intakes. The bias, or average of the differences, should be close to zero if the two methods being compared are similar. Our results for bias were $160,-25$ and $129 \mathrm{~kJ}$ for Tuesday-Thursday-Saturday, Wednesday-Friday-Sunday and Thursday-Saturday-Monday, respectively. This indicates that intake recorded on Wednesday-Friday-Sunday is the most comparable of the $3 \mathrm{~d}$ periods to the $7 \mathrm{~d}$ intake and Tuesday-Thursday-Saturday is the least comparable.

There was no significant difference between these $3 \mathrm{~d}$ periods and the $7 \mathrm{~d}$ mean for macronutrient intake (results not shown).

\section{Micronutrient intake: 7 d results}

Day-to-day variation in nutrient intake in free-living subjects is large, creating practical study design issues for researchers if more days of recording are required to evaluate habitual intake ${ }^{(6,26,27)}$. Willett ${ }^{(20)}$ reported that shorter recording periods may provide a reasonable estimation of mean intake but with overestimated standard deviations.

The UK Food Standards Agency Recommended Daily Allowance $^{(28)}$ (RDA) for vitamin A is $700 \mu \mathrm{g}$ and $600 \mu \mathrm{g}$ for men and women, respectively. The mean (SE) intake from our weighed intakes was 533 (62) $\mu \mathrm{g}$ for men (24\% below the RDA) and 501 (71) $\mu \mathrm{g}$ for women (16\% below the RDA). The mean was $513(51) \mu \mathrm{g}$ for all subjects. The UK RDA for vitamin C is $40 \mathrm{mg}$. The mean (SE) intake from our weighed intakes was 95 (9) $\mathrm{mg}$ for men (137\% above the RDA) and 96 (7) $\mathrm{mg}$ for women (140\% above the RDA). The mean was 96 (5) $\mathrm{mg}$ for all subjects, $140 \%$ 


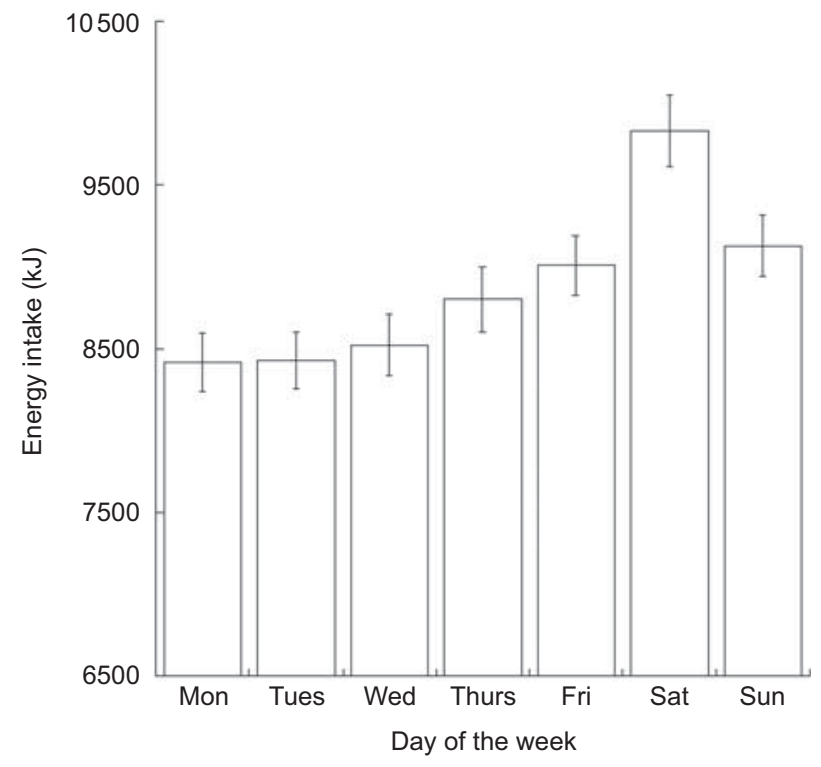

Fig. 1 Mean energy intake by day of the week among Caucasian adults ( $n$ 260), Aberdeen, north-east Scotland, UK, 2002-2004. Values are means with their standard errors represented by vertical bars. Energy intake was significantly different on Saturday and Sunday compared with the average of the weekday values $(P<0.001)$

above the RDA. The UK RDA for vitamin D is $2.50 \mu \mathrm{g}$. The mean (SE) intake from the weighed intakes was 2.98 $(0 \cdot 48) \mu \mathrm{g}$ for men (19\% above the RDA) and $2 \cdot 45$ $(0 \cdot 29) \mu \mathrm{g}$ for women ( $2 \%$ below the RDA). The mean for all subjects was $2 \cdot 64(0 \cdot 25) \mu \mathrm{g}, 6 \%$ above the RDA. The UK RDA for vitamin $\mathrm{E}$ is $4.0 \mathrm{mg}$ and $3.0 \mathrm{mg}$ for men and women, respectively. The mean (SE) intake from the weighed intakes was $6 \cdot 1(0 \cdot 4) \mathrm{mg}$ for men $(52 \%$ above the RDA) and $5 \cdot 2(0 \cdot 3) \mathrm{mg}$ for women $(73 \%$ above the RDA). The mean for all subjects was $5 \cdot 5(0 \cdot 2) \mathrm{mg}$, well above the RDA.

\section{Micronutrient intake: $7 d$ v. $3 d$}

Mean (SE) vitamin A intake on Tuesday-Thursday-Saturday was $17 \%$ lower than on Wednesday-Friday-Sunday (467 (16) $\mu \mathrm{g} v .562$ (40) $\mu \mathrm{g}, P=0.03$ ). However, none of the $3 \mathrm{~d}$ periods were significantly different (all within $12 \%)$ from the $7 \mathrm{~d}$ mean $(513(51) \mu \mathrm{g})$. No significance was found for vitamin C (all within 4\%), D (all within 7\%) or $\mathrm{E}$ (all within 3\%) when comparing the $3 \mathrm{~d}$ periods with the $7 \mathrm{~d}$ mean or with each other.

\section{Seasonal variation: energy and macronutrient intake}

In comparing seasons, no significant difference was found in average EI $(P=0.543)$. However, there was a gender $\times$ season interaction $(P=0 \cdot 019)$ with a different intake pattern for females than for males. This can be seen in Fig. 3. For females only, lower mean (SE) EI was recorded in summer (8117 $(610) \mathrm{kJ})$ and autumn (7941 (a)
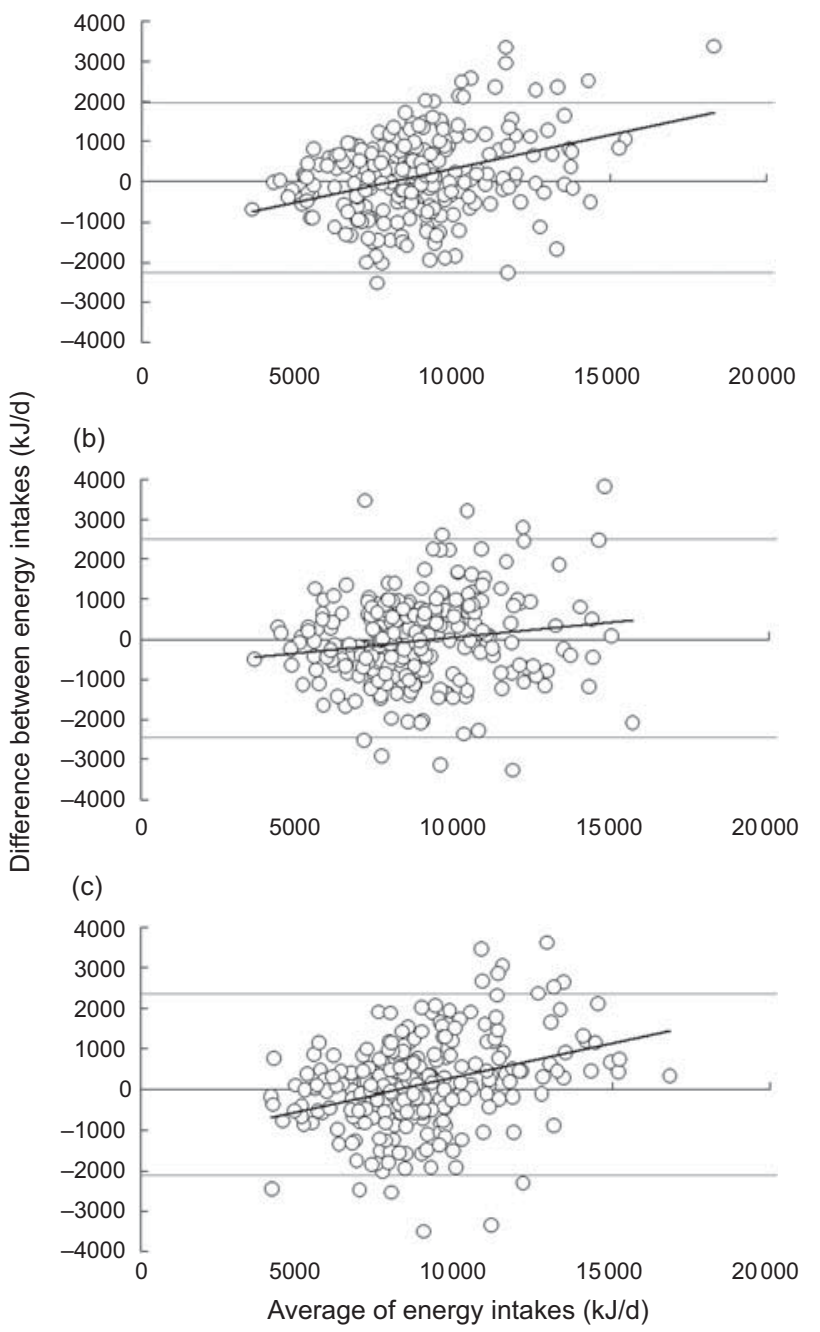

Fig. 2 Bland-Altman plots of $3 d v$. $7 d$ energy intake, with $95 \%$ confidence limits $( \pm 2 \mathrm{sD})$, among Caucasian adults (n 260), Aberdeen, north-east Scotland, UK, 2002-2004. (a) Tuesday-Thursday-Saturday $v$. Monday-Sunday $(y=$ $0 \cdot 1663 x-1328 \cdot 8, \quad R^{2}=0.127, \quad P=0.29$ ); (b) WednesdayFriday-Sunday $v$. Monday-Sunday $(y=0.0749 x-689.45$, $\left.R^{2}=0.0172, \quad P=0.94\right)$; (c) Thursday-Saturday-Monday $v$. Monday-Sunday $\left(y=0.1658 x-1352 \cdot 1, R^{2}=0.1137, P=0.30\right)$

(699) kJ) compared with that recorded in spring (8929 $(979) \mathrm{kJ})$ and winter (8132 (1041) kJ). Conversely for males, higher mean (SE) EI was recorded in summer (10 $420(736) \mathrm{kJ})$ and autumn (10 $490(1041) \mathrm{kJ})$ compared with spring (9319 (1441) kJ) and winter (9103 (1505) kJ).

There was no seasonal difference found for fat, protein or carbohydrate intake (results not shown).

\section{Seasonal variation: micronutrient intake}

Table 2 indicates the average seasonal intake for each gender of vitamins A, C, D and E over $7 \mathrm{~d}$. Vitamin A is represented as a total of retinol and carotenoids, as retinol equivalents ( $1 \mu \mathrm{g} \mathrm{RE}=12 \mu \mathrm{g}$ carotenoids). A significant difference was found between genders for vitamins D and 
$\mathrm{E}$ across all seasons but not for vitamins A or C. The intake for males was $18 \%$ higher $(P<0 \cdot 01)$ and $14 \%$ higher $(P<0 \cdot 001)$ than that for females for vitamins $\mathrm{D}$ and $\mathrm{E}$, respectively. When the data for both genders were combined, no significant difference was found with respect to season for vitamin $\mathrm{C}, \mathrm{D}$ or $\mathrm{E}$ (results not shown) and, despite a difference of $28 \%$ between the intake of vitamin A in spring and summer, there was no statistical significance.

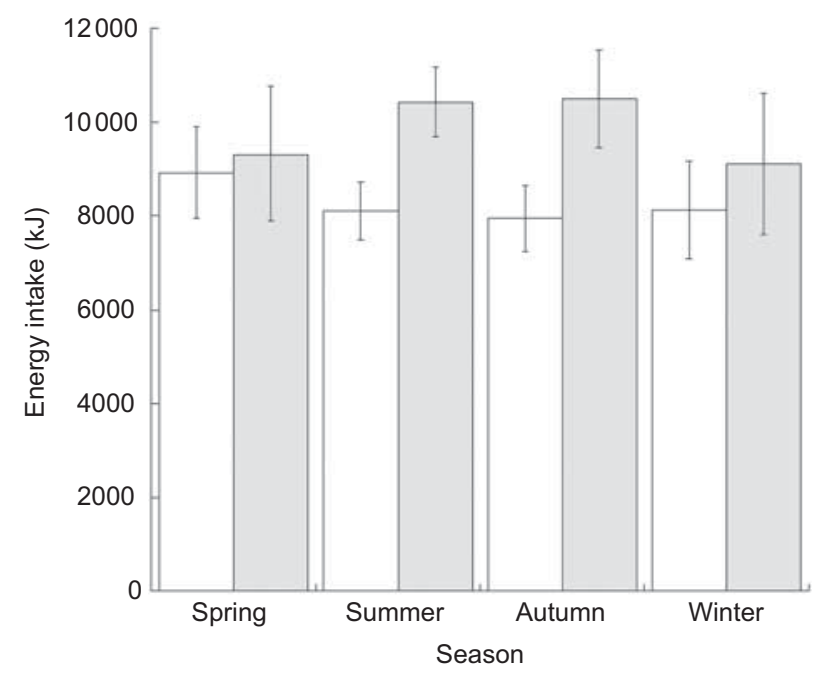

Fig. 3 Energy intake by gender ( $\square$, females; $\square$, males) and season among Caucasian adults ( $n$ 260), Aberdeen, northeast Scotland, UK, 2002-2004. Values are means with their standard errors represented by vertical bars. There was a significant gender $\times$ season interaction $(P=0.02)$; females recorded lower energy intakes in summer and autumn compared with spring and winter, while males recorded higher mean energy intakes in summer and autumn compared with spring and winter

\section{Discussion}

\section{Energy and nutrient intake results from $7 d$ and 3 d records}

The $3 \mathrm{~d}$ weighed intake is a common assessment tool in nutrition research. It has been recommended that the three days should consist of one weekend day and two weekdays $^{(7)}$ - but which three days are most representative of habitual intake? There are limited data on the variability of energy and nutrient intake with respect to either the effect of day(s) of recording or seasonal effect, but both of these issues may have practical implications for researchers conducting nutritional assessment studies. Therefore, the first aim of the current study was to compare EI results from $7 \mathrm{~d}$ food intakes with different $3 \mathrm{~d}$ periods within the same week. Average intakes for each of the seven days of the week were also examined. In accordance with previous work ${ }^{(8,9,29)}$ we found that there was a significant difference between EI collected on Monday-Friday compared with Saturday and Sunday, with the weekend EI recorded to be higher. This could have implications in the selection of which days should be collected during a $3 \mathrm{~d}$ weighed record. Most importantly, the definition of what is a 'weekend day' may be an issue of interest. We found that there was a significant difference for EI between Monday-Thursday and Friday, but not between Friday and Sunday. Does this indicate that Friday could be classified as a 'weekend day' rather than a 'weekday"? Our results for EI from all the $3 \mathrm{~d}$ periods we examined, most noticeably Wednesday-FridaySunday, were found to be comparable to the $7 \mathrm{~d}$ mean (within 3\%). Similar findings have been noted previously when comparing $3 \mathrm{~d}$ and $7 \mathrm{~d}$ EI results ${ }^{(30)}$. Our results suggest that Wednesday-Friday-Sunday should be used in future comparisons with $7 \mathrm{~d}$ intakes.

Table 2 Micronutrient intake among Caucasian adults ( $n$ 260), Aberdeen, north-east Scotland, UK, 2002-2004

\begin{tabular}{|c|c|c|c|c|c|c|c|c|c|}
\hline \multirow[b]{2}{*}{ Season } & \multirow[b]{2}{*}{ Gender $(n)$} & \multicolumn{2}{|c|}{$\begin{array}{l}\text { Vitamin A } \\
(\mu \mathrm{g})\end{array}$} & \multicolumn{2}{|c|}{$\begin{array}{l}\text { Vitamin C } \\
(\mathrm{mg})\end{array}$} & \multicolumn{2}{|c|}{$\begin{array}{l}\text { Vitamin D } \\
\qquad \mu \mathrm{g})\end{array}$} & \multicolumn{2}{|c|}{$\begin{array}{l}\text { Vitamin } E \\
(\mathrm{mg})\end{array}$} \\
\hline & & Mean & SE & Mean & SE & Mean & SE & Mean & SE \\
\hline Spring & $\begin{array}{l}\text { Male (11) } \\
\text { Female (26) } \\
\text { Both (37) }\end{array}$ & $\begin{array}{l}550 \cdot 16 \\
712 \cdot 51 \\
662 \cdot 17\end{array}$ & $\begin{array}{l}223 \cdot 73 \\
351 \cdot 98 \\
252 \cdot 57\end{array}$ & $\begin{array}{l}75 \cdot 44 \\
90 \cdot 25 \\
85 \cdot 74\end{array}$ & $\begin{array}{l}28 \cdot 23 \\
15 \cdot 35 \\
13 \cdot 72\end{array}$ & $\begin{array}{l}2 \cdot 73 \\
2 \cdot 92 \\
2 \cdot 86\end{array}$ & $\begin{array}{l}1.21 \\
0.63 \\
0.57\end{array}$ & $\begin{array}{l}5 \cdot 16 \\
5 \cdot 78 \\
5 \cdot 59\end{array}$ & $\begin{array}{l}1.05 \\
0.77 \\
0.62\end{array}$ \\
\hline Summer & $\begin{array}{l}\text { Male (46) } \\
\text { Female (67) } \\
\text { Both (113) }\end{array}$ & $\begin{array}{l}510 \cdot 27 \\
438 \cdot 22 \\
467 \cdot 55\end{array}$ & $\begin{array}{l}88 \cdot 52 \\
51 \cdot 59 \\
47 \cdot 35\end{array}$ & $\begin{array}{r}100 \cdot 96 \\
95 \cdot 66 \\
97 \cdot 82\end{array}$ & $\begin{array}{r}12 \cdot 75 \\
10 \cdot 49 \\
8 \cdot 10\end{array}$ & $\begin{array}{l}2 \cdot 86 \\
2 \cdot 45 \\
2 \cdot 62\end{array}$ & $\begin{array}{l}0.62 \\
0.49 \\
0.38\end{array}$ & $\begin{array}{l}6 \cdot 39 \\
5 \cdot 21 \\
5 \cdot 69\end{array}$ & $\begin{array}{l}0.66 \\
0.43 \\
0.38\end{array}$ \\
\hline Autumn & $\begin{array}{l}\text { Male (23) } \\
\text { Female (51) } \\
\text { Both (74) }\end{array}$ & $\begin{array}{l}611 \cdot 25 \\
436 \cdot 82 \\
490 \cdot 44\end{array}$ & $\begin{array}{r}100 \cdot 55 \\
61 \cdot 99 \\
53 \cdot 68\end{array}$ & $\begin{array}{l}96 \cdot 01 \\
98 \cdot 84 \\
97 \cdot 97\end{array}$ & $\begin{array}{r}19 \cdot 86 \\
11 \cdot 28 \\
9 \cdot 91\end{array}$ & $\begin{array}{l}3 \cdot 29 \\
2 \cdot 29 \\
2 \cdot 60\end{array}$ & $\begin{array}{l}1.05 \\
0.49 \\
0.47\end{array}$ & $\begin{array}{l}6 \cdot 51 \\
5 \cdot 20 \\
5 \cdot 60\end{array}$ & $\begin{array}{l}0.87 \\
0.48 \\
0.43\end{array}$ \\
\hline Winter & $\begin{array}{l}\text { Male (11) } \\
\text { Female (23) } \\
\text { Both (34) }\end{array}$ & $\begin{array}{l}450 \cdot 78 \\
595 \cdot 37 \\
548 \cdot 59\end{array}$ & $\begin{array}{l}164 \cdot 70 \\
268 \cdot 09 \\
189 \cdot 14\end{array}$ & $\begin{array}{l}87 \cdot 66 \\
97 \cdot 49 \\
94 \cdot 31\end{array}$ & $\begin{array}{l}19 \cdot 50 \\
20 \cdot 28 \\
15 \cdot 10\end{array}$ & $\begin{array}{l}3 \cdot 12 \\
2 \cdot 26 \\
2 \cdot 54\end{array}$ & $\begin{array}{l}1.79 \\
0.79 \\
0.79\end{array}$ & $\begin{array}{l}4 \cdot 76 \\
4 \cdot 51 \\
4 \cdot 59\end{array}$ & $\begin{array}{l}0.96 \\
0.68 \\
0.55\end{array}$ \\
\hline All & $\begin{array}{l}\text { Male }(91) \\
\text { Female (167) } \\
\text { Both }(258)\end{array}$ & $\begin{array}{l}533 \cdot 0 \\
501 \cdot 0 \\
513 \cdot 0\end{array}$ & $\begin{array}{l}62 \cdot 0 \\
71 \cdot 0 \\
51 \cdot 0\end{array}$ & $\begin{array}{l}95 \cdot 0 \\
96 \cdot 0 \\
96 \cdot 0\end{array}$ & $\begin{array}{l}9 \cdot 0 \\
7 \cdot 0 \\
5 \cdot 0\end{array}$ & $\begin{array}{l}2 \cdot 98^{\mathrm{a}} \\
2 \cdot 45^{\mathrm{b}} \\
2 \cdot 64\end{array}$ & $\begin{array}{l}0.48 \\
0.29 \\
0.25\end{array}$ & $\begin{array}{l}6 \cdot 10^{\mathrm{a}} \\
5 \cdot 20^{\mathrm{b}} \\
5 \cdot 50\end{array}$ & $\begin{array}{l}0 \cdot 40 \\
0 \cdot 30 \\
0 \cdot 20\end{array}$ \\
\hline
\end{tabular}

\footnotetext{
${ }^{\mathrm{a}, \mathrm{b}}$ Mean values within a column with unlike superscript letters were significantly different $(P<0 \cdot 05)$.
} 
The fat, protein and alcohol intakes were also significantly higher at the weekend (Saturday and Sunday) compared with weekdays (Monday-Friday), explaining the elevated EI results. This supports work carried out by Haines et al. ${ }^{(31)}$ and de Castro ${ }^{(9)}$, who also found that weekend intakes were higher for energy, fat and alcohol. Our results showed no significant differences for macroor micronutrient intake when comparing the $3 \mathrm{~d}$ results with the $7 \mathrm{~d}$ mean. This suggests that, for the evaluation of nutrient intake, a $3 \mathrm{~d}$ record is sufficient to be representative of habitual intake.

\section{Seasonal variation in energy and nutrient intake}

The second aim of the present study was to compare the energy and nutrient results for seasonal variation. Ideally, to examine seasonal variation each volunteer would have recorded four $7 \mathrm{~d}$ intakes, one in each of our designated seasons. However, this was not possible owing to practical limitations. There have been largely differing results published previously for the effect of seasonality on EI, showing no significance ${ }^{(32)}$, higher values observed in autumn/winter compared with spring/summer ${ }^{(33-35)}$ or higher values observed in winter/spring compared with summer/ autumn $^{(36,37)}$. Some studies compared winter and summer intakes only, and reported winter intakes to be significantly higher $^{(38-40)}$. It should be noted that the methodology for all of these studies varied, either in terms of subjects studied (females only ${ }^{(32-34,37,38)}$, males only ${ }^{(40)}$ or both ${ }^{(35,36,39)}$ ) or recording techniques for EI ( $7 \mathrm{~d}$ recorded intakes ${ }^{(33,34,38,39)}$, $\mathrm{FFQ}^{(36,37,40)}$ or $24 \mathrm{~h}$ recalls $\left.{ }^{(32,35)}\right)$, with no obvious pattern between methodology and results.

It has been suggested that any seasonal effect may be less pronounced in an industrialised society ${ }^{(7)}$, as more foods are available throughout the year due to improved food preservation techniques and increased importation $^{(32)}$. Despite fewer volunteers in winter/spring compared with summer/autumn (seventy-one $v$. 187), our results are in line with this suggestion; with no difference on average between seasons for the $7 \mathrm{~d}$ data from all subjects. However, there was found to be a gender $\times$ season interaction. The EI for females was lower in summer and autumn compared with spring and winter, with the converse observed for males. These results support work published previously from studies in the USA $^{(36,38)}$, China ${ }^{(37)}$ and Spain ${ }^{(39)}$ for females' EI and in Finland $^{(6)}$ for males' EI. This may be in part explained by females being more selective with food choices e.g. lowfat foods during the warmer months of the year, perhaps as an attempt at 'healthy eating', or by being more prone to 'comfort eat' in the winter.

Our results for micronutrient intake were above recommended UK values for all the vitamins we analysed for except vitamin A, supporting results published from the National Diet and Nutrition Survey ${ }^{(41)}$. This is a positive finding for the Scottish population, which is reported to have the lowest vitamin levels in Great
Britain $^{(42-44)}$ and is often referred to as the 'sick man of Europe' with respect to mortality and morbidity risk. When examining the variation in vitamin intakes, significance was found only for vitamins $\mathrm{D}(P<0 \cdot 01)$ and $\mathrm{E}$ $(P<0 \cdot 001)$ between genders. No significance was found between seasons for males, females or all subjects. Previous studies $(6,36,37,40,45)$ have looked at the actual food groups eaten, e.g. fruit and vegetables, with respect to vitamin intakes and seasonality. This could be a further area of research for this data set to examine the vitamin intakes more closely.

\section{Implications}

To collect data on habitual EI in free-living subjects, the 'gold standard' $7 \mathrm{~d}$ weighed record should ideally be used. However, our results support the use of a $3 \mathrm{~d}$ record as a suitable tool to obtain data in large nutritional studies if use of a $7 \mathrm{~d}$ record is not feasible, despite $3 \mathrm{~d}$ records being more affected by variability. Errors in self-reported dietary intakes have long been an issue under research. At least nine possible sources of errors in food intake assessment have been identified ${ }^{(7,46)}$. These errors can be attributed to subject compliance (reporting errors, wrong weights of foods, variation with time, wrong frequency of consumption, change in diet and response bias) or to the study investigators (errors from food tables, coding errors and sampling bias). In conclusion, the most representative $3 \mathrm{~d}$ period of the $7 \mathrm{~d}$ mean and therefore the best compromise in addressing the issues above is WednesdayFriday-Sunday.

\section{Acknowledgements}

Sources of funding: The authors gratefully acknowledge funding from the Scottish Executive. Conflict of interest declaration: None of the authors had a conflict of interest. Author contributions: A.M.J., J.R.S., D.M.J. and K.R. were responsible for the study concept and design. A.M.J., D.M.J., C.L.F., S.D.M. and J.S. were responsible for the data collection. C.L.F., A.M.J., S.D.M. and J.S. were responsible for the data analysis. G.W.H. was responsible for the statistical analysis. C.L.F. and A.M.J. were responsible for the first draft and all authors for critical revision of the manuscript for important intellectual content. Acknowledgments: We would like to thank all of the volunteers who participated in the studies as well as Sylvia Hay, Marion Scott and Jean Bryce for assistance in the Human Nutrition Unit.

\section{References}

1. Black AE, Goldberg GR, Jebb SA, Livingstone MB, Cole TJ \& Prentice AM (1991) Critical evaluation of energy intake data using fundamental principles of energy physiology: 2 . 
Evaluating the results of published surveys. Eur J Clin Nutr 45, 583-599.

2. Tomoyasu NJ, Toth MJ \& Poehlman ET (2000) Misreporting of total energy intake in older African Americans. Int J Obes Relat Metab Disord 24, 20-26.

3. Trabulsi J \& Schoeller DA (2001) Evaluation of dietary assessment instruments against doubly labeled water, a biomarker of habitual energy intake. Am J Physiol Endocrinol Metab 281, E891-E899.

4. Whybrow S, Horgan G \& Stubbs RJ (2008) Low-energy reporting and duration of recording period. Eur J Clin Nutr 62, $1148-1150$.

5. de Castro JM (2006) Varying levels of food energy selfreporting are associated with between-group, but not within-subject, differences in food intake. J Nutr 136, $1382-1388$

6. Hartman AM, Brown CC, Palmgren J, Pietinen P, Verkasalo M, Myer D \& Virtamo J (1990) Variability in nutrient and food intakes among older middle-aged men. Am J Epidemiol 132, 999-1012.

7. Bingham SA (1987) The dietary assessment of individuals; methods, accuracy, new techniques and recommendations. Nutr Abstr Rev 57, 705-742.

8. Taggart N (1962) Diet, activity and body-weight. A study of variations in a woman. BrJ Nutr 16, 223-235.

9. de Castro JM (1991) Weekly rhythms of spontaneous nutrient intake and meal pattern of humans. Physiol Behav 50, 729-738.

10. DEFRA Economics \& Statistics (undated) National Food Survey 2000: annual report on food expenditure, consumption and nutrient intakes. https://statistics.defra.gov.uk/esg/ publications/nfs/2000/default.asp (accessed January 2009).

11. Johnstone AM, Murison SD, Duncan JS, Rance KA \& Speakman JR (2005) Factors influencing variation in basal metabolic rate include fat-free mass, fat mass, age, and circulating thyroxine but not sex, circulating leptin, or triiodothyronine. Am J Clin Nutr 82, 941-948.

12. Johnstone AM, Rance KA, Murison SD, Duncan JS \& Speakman JR (2006) Additional anthropometric measures may improve the predictability of basal metabolic rate in adult subjects. Eur J Clin Nutr 60, 1437-1444.

13. Jackson DM, Djafarian K, Stewart J \& Speakman JR (2009) Increased television viewing is associated with elevated body fatness but not with lower total energy expenditure in children. Am J Clin Nutr 89, 1031-1036.

14. Speakman JR, Djafarian K, Stewart J \& Jackson DM (2007) Assortative mating for obesity. Am J Clin Nutr 86, 316-323.

15. Livesey G \& Elia M (1988) Estimation of energy expenditure, net carbohydrate utilization, and net fat oxidation and synthesis by indirect calorimetry: evaluation of errors with special reference to the detailed composition of fuels. $A m J$ Clin Nutr 47, 608-628.

16. Goldberg GR, Black AE, Jebb SA, Cole TJ, Murgatroyd PR, Coward WA \& Prentice AM (1991) Critical evaluation of energy intake data using fundamental principles of energy physiology: 1 . Derivation of cut-off limits to identify underrecording. Eur J Clin Nutr 45, 569-581.

17. Schofield WN (1985) Predicting basal metabolic rate, new standards and review of previous work. Hum Nutr Clin Nutr 39, Suppl. 1, 5-41.

18. Rutishauser IH (2005) Dietary intake measurements. Public Health Nutr 8, 1100-1107.

19. Nelson M, Atkinson M \& Meyer J (1997) A Photographic Atlas of Food Portion Sizes. London: MAFF Publications.

20. Willett W (1990) Nutritional Epidemiology. Oxford: Oxford University Press.

21. Friedenreich CM (1994) Methodologic issues for pooling dietary data. Am J Clin Nutr 59, 1 Suppl., 251S-252S.
22. Food Standards Agency (2002) McCance and Widdowson's The Composition of Foods, 6th summary ed. Cambridge: Royal Society of Chemistry.

23. Crawley H (1988) Food Portion Sizes. London: Food Standards Agency.

24. Bland JM \& Altman DG (1986) Statistical methods for assessing agreement between two methods of clinical measurement. Lancet 1, 307-310.

25. Department of Health (1991) Dietary Reference Values for Food Energy and Nutrients in the United Kingdom. London: HMSO.

26. Wassertheil-Smoller S, Davis BR, Breuer B, Chang CJ, Oberman A \& Blaufox MD (1993) Differences in precision of dietary estimates among different population subgroups. Ann Epidemiol 3, 619-628.

27. Thompson FE \& Byers T (1994) Dietary Assessment Resource Manual. J Nutr 124, 2245s-2317s.

28. Food Standards Agency (undated) Nutrition, Vitamins and Minerals. http://www.eatwell.gov.uk/healthydiet/nutritionessentials/vitaminsandminerals (accessed March 2008).

29. Jula A, Seppanen R \& Alanen E (1999) Influence of days of the week on reported food, macronutrient and alcohol intake among an adult population in south western Finland. Eur J Clin Nutr 53, 808-812.

30. Burnett KF, O'Connor PJ, Koltyn KF, Raglin JS \& Morgan WP (1994) Use of three-day food records as estimates of seven-day calorie intake during physical training. Med Exerc Nutr Health 3, 185-193.

31. Haines PS, Hama MY, Guilkey DK \& Popkin BM (2003) Weekend eating in the United States is linked with greater energy, fat, and alcohol intake. Obes Res 11, 945-949.

32. Van Staveren WA, Deurenberg P, Burema J, De Groot LC \& Hautvast JG (1986) Seasonal variation in food intake, pattern of physical activity and change in body weight in a group of young adult Dutch women consuming selfselected diets. Int J Obes 10, 133-145.

33. Tokudome Y, Imaeda N, Nagaya T, Fujiwara N, Sato J, Kuriki K, Kikuchi S, Maki S \& Tokudome S (2002) Daily, weekly, seasonal, within- and between-individual variation in nutrient intake according to four season consecutive 7 day weighed diet records in Japanese female dieticians. J Epidemiol 12, 85-92.

34. de Castro JM (1991) Seasonal rhythms of human nutrient intake and meal patterns. Physiol Behav 50, 243-248.

35. Ma Y, Olendzki BC, Li W, Hafner AR, Chiriboga D, Hebert JR, Campbell M, Sarnie M \& Ockene IS (2006) Seasonal variation in food intake, physical activity, and body weight in a predominantly overweight population. Eur J Clin Nutr 60, 519-528.

36. Subar AF, Frey CM, Harlan LC \& Kahle L (1994) Differences in reported food frequency by season of questionnaire administration: the 1987 National Health Interview Survey. Epidemiology 5, 226-233.

37. Fowke JH, Schlundt D, Gong Y, Jin F, Shu XO, Wen W, Liu DK, Gao YT \& Zheng W (2004) Impact of season of food frequency questionnaire administration on dietary reporting. Ann Epidemiol 14, 778-785.

38. Lee CJ, Lawler GS, Panemangalore M \& Street D (1987) Nutritional status of middle-aged and elderly females in Kentucky in two seasons: Part 1 . Body weight and related factors. I Am Coll Nutr 6, 209-215.

39. Capita R \& Alonso-Calleja C (2005) Differences in reported winter and summer dietary intakes in young adults in Spain. Int J Food Sci Nutr 56, 431-443.

40. Shahar DR, Yerushalmi N, Lubin F, Froom P, Shahar A \& Kristal-Boneh E (2001) Seasonal variations in dietary intake affect the consistency of dietary assessment. Eur $J$ Epidemiol 17, 129-133.

41. Swann G (2004) Findings from the latest National Diet and Nutrition Survey. Proc Nutr Soc 63, 505-512. 
42. Gillie O (2008) Scotland's Health Deficit: An Explanation and a Plan. London: Health Research Forum.

43. Davies PSW, Bates CJ, Cole TJ, Prentice A \& Clarke PC (1999) Vitamin D: seasonal and regional differences in preschool children in Great Britain. Eur J Clin Nutr 53, 195-198.

44. Mishra GD, Malik NS, Paul AA, Wadsworth MEJ \& BoltonSmith C (2003) Childhood and adult dietary vitamin E intake and cardiovascular risk factors in mid-life in the 1946 British Birth Cohort. Eur J Clin Nutr 57, $1418-1425$.

45. Hill TR, O'Brien MM, Cashman KD, Flynn A \& Kiely M (2004) Vitamin D intakes in 18-64-y-old Irish adults. Eur J Clin Nutr 58, 1509-1517.

46. Stubbs RJ, Johnstone AM, O'Reilly LM \& Poppitt SD (1998) Methodological issues relating to the measurement of food, energy and nutrient intake in human laboratory-based studies. Proc Nutr Soc 57, 357-372. 